\title{
Retrograde migration of ventriculoperitoneal shunt to the neck. Case report
}

\author{
M. Felipe-Murcia*; M.J. Almagro* and J.F. Martínez-Lage**
}

*Servicio Regional de Neurocirugía. Hospital Universitario Virgen de la Arrixaca. **Laboratorio de Neurología y Neurocirugía Experimental (Grupo NYNE). Facultad de Medicina. Murcia.

\section{Summary}

We report a patient, given a ventriculoperitoneal shunt at the neonatal period, who presented with a painless subcutaneous mass on his neck. Plain radiographs of the cervical region showed that the swelling was made up by a migrated and coiled peritoneal catheter. We briefly discuss the proposed mechanism for this complication and suggest that this occurrence must be taken into account at the time of evaluating a patient with shunt malfunction.

KEY WORDS: Retrograde migration of shunts. CSF shunt complications. Ventriculoperitoneal shunt. Hydrocephalus.

Migración retrógrada del catéter peritoneal de una válvula de hidrocefalia al cuello. Descripción de un caso

\section{Resumen}

Describimos el caso de un adulto que había sido tratado de recién nacido mediante la colocación de una válvula ventriculoperitoneal que se presentó con una tumoración indolora en el cuello. La radiografía simple demostró que la masa estaba formada por el catéter peritoneal que había emigrado cranealmente y se había enrollado en el subcutáneo. Discutimos brevemente los posibles mecanismos para explicar esta complicación y sugerimos que esta posibilidad sea tenida en cuenta a la hora de valorar un paciente con malfunción de una derivación de LCR.

PALABRAS CLAVE: Migración retrógrada de las válvulas. Complicaciones de las derivaciones de LCR. Derivación ventriculoperitoneal. Hidrocefalia.

\section{Introduction}

Shunting of CSF constitutes the most frequent form

Recibido: 19-10-05. Aceptado: 21-11-05 of treatment for hydrocephalus. Complications related to shunt use are commonly classified as infectious, mechanical or functional. Mechanical complications, especially those related to shunt-parts disconnection and downward catheter migration have diminished with the growing use of shunts made up with soldered pieces. Although rarely, all components of the shunt systems (reservoir, valve and ventricular or distal catheters) may be displaced from their original position and migrate to diverse parts of the body ${ }^{1-14}$. The retrograde migration of peritoneal or venous catheters through the subcutaneous tract of the shunt tubing has been reported in several occasions ${ }^{1-6,8-14}$. In this work we describe a patient with a ventriculoperitoneal shunt (VPS) that had migrated upwards and coiled under the skin of the neck.

\section{Case report}

A 20-year-old man was seen at the Outpatient Clinic for routine review of myelomeningocele hydrocephalus after having moved to our city. Past history revealed that he had been operated, as a newborn, for myelomeningocele and given a VPS 3 weeks later. On clinical examination, a painless subcutaneous swelling was palpated on his right supraclavicular region. From this place downwards the shunt tubing could not be palpated. There were no subcutaneous collections of fluid. Plain radiographs of the CSF draining system disclosed that the swelling consisted of the shunt peritoneal catheter that appeared coiled, being the distal part of the tubing missing from its expected course (Figure). A computerized tomography scan of the head revealed slightly enlarged ventricles but without neuroimaging signs of activity of the hydrocephalus. As the patient was asymptomatic, he refused a surgical revision of the shunt. He was warned about this possibility arising in the future.

\section{Discussion}

Several unusual complications due to the dislocation of the shunts components have been reported. Even the valve 


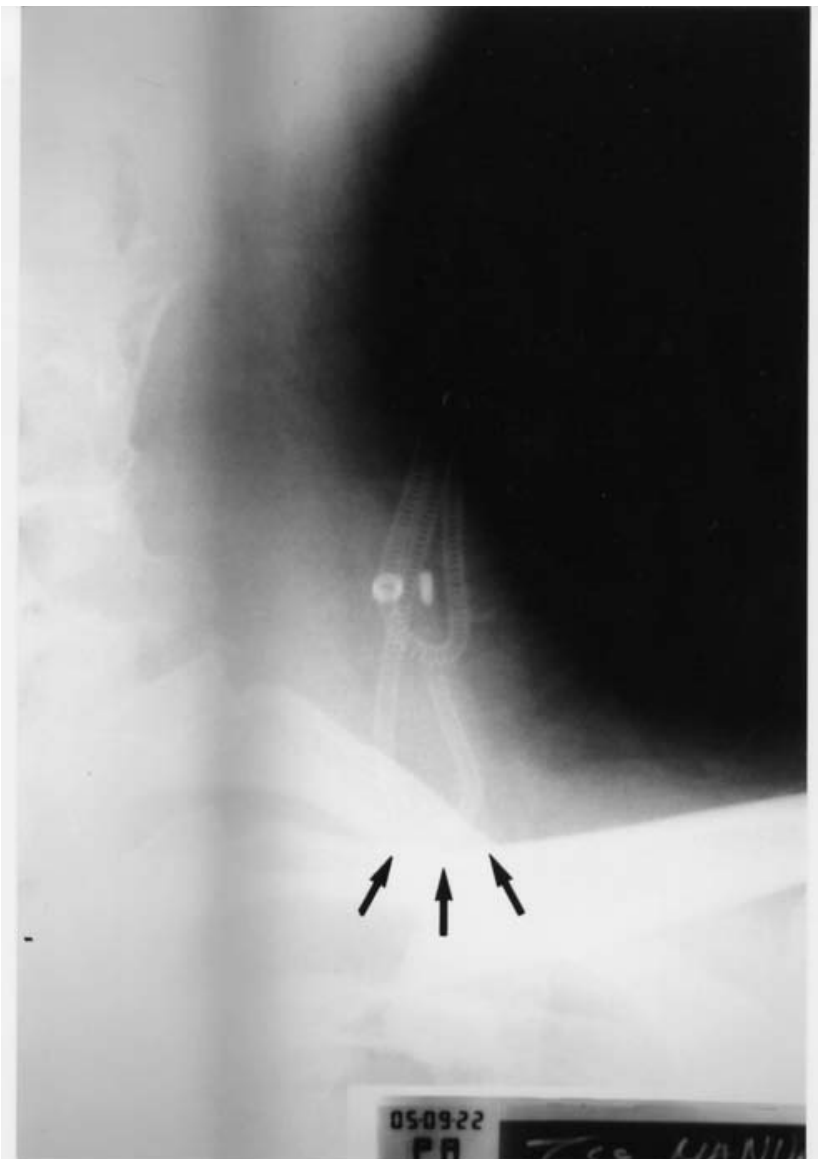

Figure. Plain radiograph showing subcutaneous coiling of the whole Raimondi peritoneal catheter in the patient's neck (arrows)

itself or the reservoir has been found to penetrate within the skull ${ }^{7}$. Disconnection and downward migration of the distal catheters within the peritoneal cavity used to be a frequent complication in the so-called 3-piece shunts, a problem that is now almost completely unknown due to the construct of unitized valves or shunts with soldered components. Migration and extrusion of distal catheters have been reported through several organs and body orifices or through the cervical or abdominal wounds. A literature review of all possible sites for shunt migration is beyond the scope of our paper.

Apparently, Scott et al. were the first to illustrate the complete migration of a valveless tube within the cerebral ventricles in one of the early reports on VPS in children ${ }^{12}$. Conan et al. reported the retrograde migration of the catheter of ventriculoatrial shunts within the internal jugular vein in two adult patients ${ }^{2}$. Others have also documented penetration of shunts within the cerebral ventricles ${ }^{1,9,10,13,14}$. Most instances of this occurrence have been related with the use of unishunts and valveless systems ${ }^{1,12,13}$. Subcutaneous coiling at the scalp adjacent to the burr-hole has also been illustrated in several cases ${ }^{3,5,6,11}$. To our knowledge there is only another instance of relocation of the whole shunt system in the subcutaneous tissues at the supraclavicular region ${ }^{6}$. The proposed mechanisms to explain this upward migration of the shunt include loose or inadequate fixation of the tubing to the pericranium, lack of a reservoir, too a long catheter, faulty technique, excessive subcutaneous undermining etc. ${ }^{1,2,6,9,10,13}$. In a recent work, Domínguez et al. report the complete coiling of an Orbis Sigma valve within the scalp of a child and attribute this occurrence to the retained "memory" of the shunt material within its sterile package ${ }^{3}$.

In 1993, we reported three patients with symptoms of shunt malfunction that were found to have a retrograde migration of the peritoneal catheter to the subcutaneous tissues of the chest wall ${ }^{8}$. In all three cases, as in the one that we report now, the system contained a spring-reinforced Raimondi catheter. We propose that the mechanism to explain the upward tube displacement is due to the abrupt release of the anchoring point formed by the abdominal scar around the catheter that is suddenly stretched, in this way the tube exits the abdominal cavity being unable to return to $\mathrm{it}^{8}$. CSF pouring through the shunt, that continues functioning, further eases the tube upward movement.

The diagnosis of this complication is easily accomplished by palpation of the integrity of the drainage system and may be confirmed by shunt radiographs. We suggest that, given the multiplicity of CSF drainage systems, the possibility of shunt migration should be borne in mind in the differential diagnosis of patients presenting with symptoms and signs of shunt malfunction.

\section{References}

1. Alvarez Garijo, J.A., Pecourt, J.C., de la Resurrección, M.: Migration of ventriculo-peritoneal shunt into the lateral ventricle of an adult. Surg Neurol 1979; 11:3 99-400.

2. Conan, M.A., Allen Jr, M.B.: Retrograde migration of the venous catheter as a complication of ventriculoatrial shunts in adults. J Neurosurg 1971; 35: 348-350.

3. Domínguez, C.J., Tyagi, A., Hall, G., Timothy, J., Chumas, P.D.: Sub-galeal coiling of the proximal and distal components of a ventriculo-peritoneal shunt. An unusual complication and proposed mechanism. Childs Nery Syst 2000; 16: 493-495.

4. Ferraresi, S., Griffin, C., Torcello, L., Cassinari, V.: Duplicated peritoneal catheter as a cause of shunt malfunction. Case report. Neurosurg Rev 1991; 14: 149-150.

5. Heim, R.C., Kaufman, B.A., Park, T.S.: Complete migration of peritoneal shunt tubing to the scalp. Childs Nery Syst 1994; 10: 399-400.

6. Kim, K.J., Wang, K.C., Cho, B.K.: Proximal migration and subcutaneous coiling of a peritoneal catheter: report of 
two cases. Childs Nery Syst 1995; 11: 428-431.

7. Martínez-Lage, J.F., Poza, M., Esteban, J.A.: Mechanical complications of the reservoirs and shunting devices in ventricular shunt systems. Br J Neurosurg 1992; 6: 321326.

8. Martínez-Lage, J.F., Poza, M., Izura, V.: Retrograde migration of the abdominal catheters as a complication of ventriculoperitoneal shunts: the fishhook sign. Childs New Syst 1993; 9: 425-427.

9. Mazza, C., Briccolo, A.: Upward dislocation of peritoneal catheter into the ventricular cavity. A rare complication of the ventriculo-peritoneal shunt. Report of a case. Neuropttdiatrie 1975; 6: 313-316.

10. Mori, K., Yamashita, J., Handa, H.: "Missing tube" of peritoneal shunt: migration of the whole system into the ventricle. Surg Neurol 1975; 4: 57-59.

11. Pang, D., Wilberger, J.F.: Upward migration of peritoneal tubing. Surg Neurol 1980; 14: 363-364.
12. Scott, M., Wycis, H.T., Murtagh, F., Reyes, V.: Observations on ventricular and lumbar subarachnoid peritoneal shunts in hydrocephalic patients. J Neurosurg 1955; 12: 165175.

13. Villarejo, F., Alvarez-Sastre, C., Giménez, D., González, C.: Migration of an entire shunt into the ventricle. Neurochirurgia 1979; 22: 196-198.

14. Young, H.A., Robb, P.J., Hardy, D.G.: Complete migration of ventriculo-peritoneal shunt into the ventricle: report of two cases. Neurosurgery 1983; 12: 469-471.

Felipe-Murcia, M.; Almagro, J.M.; Martínez-Lage, J.F.: Retrograde migration of ventriculoperitoneal shunt to the neck. Case report. Neurocirugía 2006; 17: 450-452.

Correspondencia postal: Dr. Juan F. Martínez-Lage. Servicio Regional de Neurocirugía. Hospital Universitario "Virgen de la Arrixaca" El Palmar, E-30120 Murcia. 